\title{
Identifying long-distance transport of archaeological obsidian across the ancient North American landscape
}

\author{
RHY MCMILLAN ${ }^{1,2 *}$, DOMINIQUE WeIS ${ }^{1,2}$, \\ MARGHALERAY AMINI ${ }^{1,2}$, AVIVA RATHBONE ${ }^{2,3}$ \\ ${ }^{1}$ Pacific Centre for Isotopic and Geochemical Research \\ (PCIGR), University of British Columbia (UBC) \\ ${ }^{2}$ UBC Indigenous/Science Research Excellence Cluster \\ ${ }^{3}$ Musqueam ( $\left.\mathrm{x}^{\mathrm{w}} \mathrm{m} ə \theta \mathrm{k}^{\mathrm{w}} ə \mathrm{y} ə \mathrm{~m}\right)$ Indian Band \\ * correspondence: rmcmillan@eoas.ubc.ca
}

Obsidian, or volcanic glass, is frequently found in archaeological sites in western North America. Researchers often investigate ancient Indigenous landscape use by comparing the trace element concentrations of archaeological obsidian objects to natural sources. However, the trace element compositions of obsidian sources are not necessarily unique, potentially leading to inaccurate conclusions when used in isolation. To obtain more diagnostic information, we developed a multi-proxy sourcing procedure for the region, called 'Splitting Obsidian'. It combines 1) the investigation of structural characteristics with non-destructive Raman spectroscopy and 2) the measurement of trace element concentrations and $\mathrm{Pb}$ isotope ratios with minimally invasive split stream laser ablation inductively coupled plasma mass spectrometry (SS-LA-ICP-MS). The PCIGR set-up permits simultaneous in-situ measurement of trace element concentrations $(<5 \%, 2 \mathrm{RSD})$ on an quadrupole ICP-MS and $\mathrm{Pb}$ isotope ratios $(1-2 \%, 2 \mathrm{RSD})$ on a high-resolution sector field ICP-MS, both coupled to a RESOlution M-50-LR ArF excimer laser system $(193 \mathrm{~nm})$. Using this approach, we investigated the geographic origins of 13 small $(<1 \mathrm{~cm}$ in length) fragments of obsidian ('micro-belongings') exhumed from a key $\mathrm{x}^{\mathrm{w}} \mathrm{m} ə \theta \mathrm{k}^{\mathrm{w}}$ əy่əm (Musqueam) archaeological site near modern-day Vancouver, Canada. A comparison of measured characteristics of the micro-belongings with those of potential geologic sources indicates that four of them most likely originated from Browns Bench (Idaho), $1000 \mathrm{~km}$ southeast of the site. We initially identified this source as a candidate by comparing the $\mathrm{Pb}$ isotopic compositions of the four micro-belongings to those of rhyolites from the Snake River Plain. The remainder of the fragments likely originated from Glass Buttes (Oregon), $\sim 670 \mathrm{~km}$ south-southeast of the site. These outcomes would not have been possible using a traditional, single-proxy sourcing approach, and such records of long-distance transport provide key lines of evidence for the continuity of $\mathrm{x}^{\mathrm{w}} \mathrm{m} \partial \theta \mathrm{k}^{\mathrm{w}} \partial \mathrm{y} \partial \mathrm{m}$ social and material networks and use of the ancient North American landscape.

[1] McMillan et al. (2019) J. Archaeol. Sci. Rep. 28, 102040. 